\title{
DAMPAK EKONOMI DAN SOSIAL WISATA ALAM BERBASIS MASYARAKAT DALAM KONTEKS PEMBERDAYAAN MASYARAKAT: STUDI KASUS PADA DESA WISATA BEJIHARJO, KEC. KARANGMOJO, KAB. GUNUNGKIDUL
}

\author{
Hiryanto, Lutfi Wibawa, dan Entoh Tohani \\ Universitas Negeri Yogyakarta \\ Email: hiryanto@uny.ac.id
}

\begin{abstract}
Abstrak
Penelitian ini bertujuan untuk mendeskripsikan 1) Dampak ekonomi dan sosial wisata alam berbasis masyarakat dalam konteks pemberdayaan masyarakat, 2) Pola pengembangan jejaring dalam penyelenggaraan wisata alam berbasis masyarakat dalam meningkatkan pelayanan wisata. Penelitian kualitatif dengan model studi kasus, dilakukan di kawasan wisata alam berbasis masyarakat yang ada di desa Bejiharjo, Karangmojo, Gunung Kidul. Pengumpulan data, dilakukan melalui observasi, dokumentasi dan wawancara terhadap pengelola pokdawis Dewobejo, Wirawisata, Pancawisata dan perangkat desa serta tokoh masyarakat. Teknis analisis data menggunakan teknik analisis kualitatif model interaktif dari Milles dan Hubberman, Keabsahan data didukung dengan teknik triangulasi metode dan sumber, perpanjangan pengamatan dan diskusi terfokus. Hasil penelitian menunjukkan, pertama, keberadaan objek wisata Goa Pindul menyebabkan perubahan dalam a) perekonomian masyarakat, ditandai dengan adanya perubahan jenis pekerjaan yang dimiliki pelaku wisata dan masyarakat sekitar objek wisata, dan adanya peningkatan penghasilan walaupun belum pada semua level masyarakat; b) terjadi perubahan perilaku individu, namun nilai, tradisi dan adat kebiasaan serta peningkatan kebutuhan pendidikan relatif tidak berubah. Kedua, pola jejaring yang terbangun di antara para pelaku wisata Goa Pindul tidak mengindikasikan adanya perbedaan keragaman hubungan dengan pihak lain. Pencarian sumber daya lebih banyak dilakukan dengan pihak yang memiliki kesamaan kepentingan atau perhatian dalam pengembangan kepariwisataan di Kabupaten Gunungkidul.
\end{abstract}

Kata kunci: dampak sosial ekonomi, desa wisata, jejaring

\section{ECONOMIC AND SOCIAL IMPACT OF NATURAL TOURISM BASED ON COMMUNITY EMPOWERMENT CONTEXT: CASE STUDY ON BEJIHARJO, KARANGMOJO, GUNUNGKIDUL}

\begin{abstract}
This study aims to describe 1) The economic and social impact of community-based tourism in the context of community empowerment, 2) Pattern of network development in the implementation of community-based nature tourism in improving tourism services. Qualitative research with case study model, conducted in nature-based nature tourism area in the village of Bejiharjo, Karangmojo, Gunung Kidul. Data collection, conducted through observation, documentation and interviews of Dewobejo pokdawis, Wirawisata, Pancawisata and village officials as well as community leaders. Technical data analysis using qualitative analysis techniques of interactive models from Milles and Hubberman, The validity of data supported by triangulation techniques methods and sources, extension of observation and focused discussion. The result of the research shows, firstly, the existence of Goa Pindul tourist attraction caused a change in a) the society economy, marked by the change of work type owned by the tourism actors and the society around the tourism object, and the increase of income although not yet at all level of society; b) there is a change in individual behavior, but the values, traditions and customs and the increase in educational
\end{abstract}


needs are relatively unchanged. Secondly, the networking pattern that was built among the actors of Goa Pindul tourism did not indicate any differences in the diversity of relationships with other parties. The search for more resources is carried out with parties with similar interests or concerns in tourism development in Gunungkidul Regency.

Abstract: economic-sosial impact, tourism village, network

\section{PENDAHULUAN}

Daerah Istimewa Yogyakarta (DIY) merupakan salah satu tujuan wisatawan baik lokal maupun luar daerah yang menyimpan beragam tujuan wisata baik wisata alam maupun wisata buatan. Jumlah obyek wisata di DIY tahun 2012 yang meliputi obyek wisata alam, obyek wisata budaya, obyek wisata buatan, dan desa atau kampung wisata adalah sebanyak 265 obyek wisata. Keseluruhan kunjungan wisatawan mancanegara ke obyek-obyek wisata tersebut sebanyak 499.515 orang, sedangkan wisatawan nusantara mencapai 10.880.125 orang, sehingga totalnya mencapai 11.379.640 orang (Dinas Pariwisata DIY, 2013:2). Informasi lain menunjukkan bahwa jumlah kunjungan wisatawan hampir setiap tahun mengalami peningkatan, misalnya pada tahun 2014 mencapai 2,3 juta wisatawan dengan puncak kunjungan terjadi pada hari libur (www.krjogja.com). Tingginya jumlah pengunjung ke obyek wisata menggambarkan adanya perpindahan aliran sumberdaya yang masuk ke suatu masyarakat. Sudah tentu, sumberdaya atau keuntungan yang diperoleh oleh kelompok atau masyarakat penyelenggara wisata harus dapat dimanfaatkan secara adil dan bermanfaat untuk kepentingan pengembangan masyarakat secara luas.

Salah satu tujuan wisata yang akhir-akhir ini berkembang di masyarakat adalah wisata alam (nature tourism) yang dikelola sendiri oleh masyarakat atau wisata alam berbasis masyarakat. Dalam penyelenggaraan aktivitas wisata, masyarakat memiliki kewenangan dalam pengambilan keputusan mengenai penyelenggaraan wisata alam baik dalam perencanaan, pelaksanaan, maupun pemanfatan dan evaluasi aktivitas wisata. Keberadaan wisata alam berbasis masyarakat diharapkan dapat memberikan manfaat ekonomi maupun sosial yang lebih besar, di mana mampu menjadi sumber pendapatan bagi warga masyarakat sekitar sehingga mampu meningkatkan kesejahteraan warga masyarakat. Pada tahun 2000, pengembangan wisata berbasis masyarakat telah mendapatkan perhatian serius dari Bank Dunia yang menggerakkan konsep "tourism based community development" sebagai upaya mengatasi kemiskinan. Konsep ini dipandang sebagai alternatif pengembangan aktivitas pariwisata yang menekankan dan memanfaatkan partisipasi masyarakat lokal untuk menggerakkan atau memajukan ekonomi dan sosialnya (Luccheti \& Font, 2013:3).

Dalam konteks ekonomi, adanya objek wisata alam akan berdampak pada peningkatan penghasilan maupun beragamnya jenis pekerjaan, karena objek wisata memungkinkan pelaku maupun masyarakat sekitar bisa bekerja sebagai pemandu, pedagang makanan maupun oleh-oleh, pengelola, dan sebagainya, yang tentunya akan menyebabkan meningkatnya pendapatan atau penghasilan, sementara dalam konteks sosial pengembangan aktivitas pariwisata

Keberhasilan pengelolaan wisata alam berbasis masyarakat tidak lepas dari selain dari kemampuan penyediaan layanan jasa wisata langsung ke konsumen, juga ditentukan oleh kemampuan pengelola dalam membangun dan mengembangkan jejaring (networking) atau kemampuan berkolaborasi dengan semua pihak yang terkait dalam keberadaan suatu obyek wisata dimana aktivitas wisata alam melibatkan banyak pihak (Luccheti \& Front, 2013:4). Kemampuan membina jejaring baik internal pengelola maupun dengan pihak 
eksternal memungkinkan pencapaian atau diperolehnya sumberdaya yang lebih kualitas yang akhirnya dapat meningkatkan pendapatan para pelaku wisata, peningkatan aktivitas pertukaran pengetahuan dan informasi, dan lebih jauh adalah dapat membantu mengembangkan atau memberdayakan suatu masyarakat tertentu dimana objek wisata tersebut dikembangkan.

Selain itu, penguasaan kepemilikan kapasitas membangun jejaring dari para pelaku wisata alam (nature tourism) disebabkan adanya pemikiran bahwa wisata alam yang terdapat di masyarakat merupakan suatu potensi atau keunggulan komperatif. Keunggulan ini tidak akan dapat memberikan manfaat yang besar apabila sumberdaya manusia baik pelaku maupun masyarakat sekitarnya tidak mendapatkan tindakan edukatif yang bertujuan pada pengusaaan kemampuan di bidang pelayanan jasa wisata. Dengan kata lain, keunggulan komperatif (comperative advantages) perlu dikembangkan melalui pengembangan keunggulan kompetitif (competitive advantages).

Dalam realita, tidak jarang wisata alam yang ada dan dikelola masyarakat kurang dapat memberikan manfaat yang besar terhadap kemajuan masyarakat karena minimnya kunjungan dari para wisatawan. Hal ini disebabkan selain kegiatan promosi yang kurang, aktivitas jejaring yang dilakukan oleh para pelaku wisata alam masih sangat terbatas dilakukan dan/atau jejaring yang terbangun kurang berjalan baik sehingga dalam perkembangannya menimbulkan kerugian. Sebagai contoh, aktivitas wisata di Karangmojo, Gunung Kidul dengan obyek wisata alam berupa gua Pindul yang akhirakhir ini berkembang, mengalami gejolak akibat kekurangterbangunnya jejaring positif yang baik dalam pengelolaan wisata alam. Ditandai dengan muncul konfliks dalam pengelolaan wisata alam yang berakibat pada penurunan citra wisata dan kemanfaatan ekonominya (www.krjogja. com).
Permasalahan itu dipandang penting untuk melakukan penelitian yang berusaha menjelaskan dampak ekonomi dan sosial dari wisata alam dalam konteks pemberdayaan masyarakat dan kemampuan membangun jejaring dari para pelaku wisata alam berbasis masyarakat yang bermanfaat pada peningkatan sumberdaya manusia di bidang pariwisata, rekreasi, dan pengisian waktu luang.

\section{METODE}

Penelitian yang dilakukan ini merupakan penelitian kualitatif dengan model studi kasus yang berusaha menjawab pertanyaan "bagaimana" dan "mengapa" dari suatu/kejadian (Yin, 2003:231) dalam konteks tertentu. Penelitian ini berusaha memahami aktivitas sosial atau orang baik individu atau kelompok. Penelitian ini bertujuan untuk mengetahui dampak penyelenggaraan wisata alam berbasis masyarakat terhadap perubahan ekonomi, sosial, dan pendidikan bagi para pelaku wisata dan masyarakat sekitarnya dan tingkat kompetensi pengelola wisata dalam membina jejaring dalam rangka mengembangkan masyarakat.

Penelitian ini dilakukan di kawasan wisata alam berbasis masyarakat desa Bejiharjo, Karangmojo, Gunung Kidul. Penentuan unit analisis ini dilakukan dengan mempertimbangkan aspek pertumbuhan dan perkembangan wisata alam tersebut yang akhir-akhir ini menunjukkan perkembangan yang pesat, ditandai dengan animo masyarakat dan kemunculan aktivitas ekonomi di lingkungannya. Pengambilan informan dan/atau responden juga dilakukan menggunakan teknik purposive.

Pengumpulan data menggunakan teknik wawancara, observasi, dokumentasi, dilengkapi dengan pedoman wawancara, observasi dan pedoman dokumentasi. Analisis data dengan menggunakan teknik analisis kualitatif model interaktif (Miles \& Huberman, 2007:256). Keabsahan data dilakukan dengan menggunakan teknik triangulasi 
metode dan sumber, perpanjangan pengamatan dan diskusi terfokus.

\section{HASIL DAN PEMBAHASAN}

Hasil penelitian mengacu pada fokus kajian atau penelitian yang mencakup: dampak ekonomi dan sosial budaya dari obyek wisata Gua Pindul, pola jejaring pelaku wisata goa Pindul, dan kendala-kendala yang dihadapi oleh pelaku wisata dapat dideskripsikan sebagai berikut. Pelaku wisata yang dijadikan subyek penelitian mencakup 3 operator wisata yaitu yakni Pokdarwis Dewa Bejo, Pokdarwis Pancawisata dan Pokdarwis Wirawisata.

\section{Perubahan kehidupan perekonomian pada pelaku wisata dan masyarakat}

Goa Pindul yang terletak di Desa

Bejiharjo, Kecamatan Karangmojo, Kabupaten Gunung Kidul merupakan salah satu obyek wisata yang dikembangkan oleh masyarakat setempat. Sebelum Goa Pindul dijadikan sebagai obyek wisata di desa Bejiharjo Kecamatan Karangmojo, kawasan ini digunakan oleh penduduk sekitar sebagai pembuangan sampah. Dengan berjalannya waktu pemerintah melihat potensi dari Goa Pindul yang dapat dijadikan sebagai obyek wisata sehingga dapat meningkatkan perekonomian penduduk desa Bejiharjo baik dari segi peningkatkan pendapatan dan penyerapan tenaga kerja yang lebih tinggi sehingga dapat mengurangi tingkat pengangguran. Pada tahun 2010 Goa Pindul secara resmi dibuka oleh pemerintah setempat sebagai salah satu obyek wisata.

Kehadiran Goa Pindul telah memberikan banyak kontribusi untuk kelangsungan hidup warga setempat. Hingga kini, obyek wisata Goa Pindul telah menyerap sekitar 150 orang tenaga kerja, sebagian besar dari mereka adalah warga yang tinggal di sekitar Desa Wisata Bejiharjo. Mereka menempati berbagai posisi, seperti pemandu (tour guide), security, penjaga kebersihan, bagian manajemen dan keuangan, serta marketing. Sekitar 2000-3000 pengunjung kini bisa diserap oleh obyek wisata Goa Pindul. Penghasilan yang didapatkan dari obyek wisata Goa Pindul disumbangkan untuk Desa Wisata Bejiharjo sebanyak 25 juta rupiah/tahun.

Kehadiran obyek wisata Goa Pindul telah merubah kehidupan perekonomian para pelaku wisata dan masyarakat sekitar. Di kawasan ini terdapat sebanyak 10 operator wisata, dengan tiga operator yang sudah lama berjalan dan berkembang. Perubahan perekonomian masyarakat Desa Bejiharjo, dan umumnya masyarakat Karangmojo ditandai dengan peningkatan ketersediaan lapangan kerja dalam bidang pariwisata dan dapat memberikan pendapatan yang lebih baik bagi para warga masyarakat sekitar. Adanya perubahan ini diakui oleh para pengelola dan perangkat desa sebagaimana dikatakan oleh HP, seorang perangkat desa Bejiharjo, yang menyatakan bahwa adanya objek wisata gua Pindul telah menyebabkan perubahan pada jenis pekerjaan, yang mana semula warga masyarakat bekerja sebagai petani, pedagang, tukang batu,wiraswasta, buruh pabrik dan petani ikan, berubah menjadi pemandu, koordinator lapangan, petugas parkir, fotografer, pengurus kelompok sadar wisata, pedagang dan petugas keamanan serta pemasaran. Pernyataan yang senada juga sampaikan juga oleh AN, salah seorang dukuh dimana objek wisata itu berada, bahwa:

"Adanya objek wisata gua pindul
menyebabkan perubahan
perkerjaan penduduk yang tadinya
mayoritas petani dan buruh,
menjadi sebagian besar ikut
pokdarwis karyawisata, tetapi
sebagian masih ada yang tetap
menjadi petani dan dagang
makanan kecil-kecil" (Wawancara,
03/09/2015).

Keberadaan desa wisata telah merubah pekerjaan mayoritas penduduk desa Bejiharjo. Pada umumnya sebelum ditemukan obyek wisata Goa Pindul dan akhirnya berkembang obyek wisata Goa 
Pindul, para warga masyarakat memiliki pekerjaan sebagai petani dengan sistem pertanian tadah hujan dan sebagai pedagang keliling di kota Yogyakarta. Namun, sejak berkembangnya industri wisata di wilayah ini, mereka beralih pekerjaan yaitu terlibat mengelola wisata dengan beragam pekerjaan seperti menjadi pemandu, tukang parkir, penyedia makanan, dan sebagainya. Banyaknya penduduk yang beralih pekerjaan ternyata menimbulkan dampak terhadap ketenagakerjaan di bidang pertanian yaitu berkurangnya tenaga yang mengelola pertanian. Akibat kekurangan tenaga kerja ini, banyak pemilik pertani menggunakan tenaga kerja atau buruh buruh tani di luar wilayah desa Bejiharjo sebagaimana dikatakan oleh pengelola pokdarwis Dewabejo, pak Gun:

"Secara tidak langsung adanya objek wisata gua Pindul tenaga kerja di pertanian berubah, lebih fokus di wisata, tenaga petani mengambil dari luar dan harus membayar yang lebih mahal dari tenaga kerja yang ada, tetapi ya nggak apa toh sudah dapat penghasilan dari objek wisata dan lahan pertanian tetap ada yang menggarapnya." (Wawancara 03/09/2015)

Perubahan lain yang terjadi dalam masyarakat dengan berkembangnya desa wisata Bejiharjo adalah terkait dengan peningkatan pendapat dan pengeluaran yang dilakukan oleh pelaku wisata maupun oleh masyarakat. Hasil penelitian yang diperoleh melalui wawancara terbuka menunjukkan bahwa pada umumnya pelaku wisata ketika menjadi petani memiliki penghasilan Rp 25.000 setiap hari dan Rp 45.000 setiap hari untuk pedagang, berubah menjadi Rp 45.000 300.000 per hari sebagai pemandu atau 2 juta -4 juta per bulan. Namun, kenaikan pendapatan warga masyarakat diikuti dengan kenaikan pengeluaran, di mana pengeluaran yang semula sebelum terlibat sebagai pelaku wisata memiliki pengeluaran tiap hari antara Rp $20.000-$ 40.000, berubah menjadi $50.000-150.000$ per hari setelah terlibat. Peningkatan pengeluaran ditandai dengan konsumsi warga masyarakat yang terlibat dalam obyek wisata terhadap barang atau jasa elektronik, otomotik, dan keperluan sandang untuk kehidupan berkeluarga. Perubahan ini diakui oleh para pelaku obyek wisata baik dari Dewabejo, Pancawisata, maupun Wirawisata, dan para tokoh masyarakat, yang mana pendapat mereka pada prinsipnya sama yaitu berkembangnya objek wisata telah meningkatkan penghasilan pelaku wisata maupun masyarakat sekitar lebih dari 100 $\%$, tiap harinya.

Wujud perubahan terkait dengan perekonomian yang meningkat dari warga masyarakat di Bejiharjo yang nampaknya cukup menyolok adalah kepemilikan harta benda. Semula pada saat masih menjadi petani atau pedagang, harta yang dimiliki terdiri dari sepeda, televisi, sepeda motor, tetapi setelah bekerja pada objek wisata terjadi peningkatan dalam kepemilikan harga, seperti yang dikemukakan oleh HP, seorang perangkat desa, HP menyatakan: "tadinya ada penduduk yang hanya memiliki sepeda, TV dan handphone, tetapi sekarang sudah punya sepeda motor, mobil, rumah, perhiasan, laptop, lemari es dan tanah pekarangan". Pernyataan ini juga ditegaskan oleh perangkat desa yang lain AW, yang menyatakan bahwa ketika masih bertani harta bendanya hanya sepeda ontel, tetapi sekarang sudah punya motor dan mobil, selain itu juga telah memiliki budaya untuk menabung, yang selama ini ketika masih bekerja sebagai petani belum dapat menabung karena tidak ada sisa penghasilan yang bisa ditabung.

Perubahan pada pemuda yang ada Bejiharjo. Sebelum berkembang obyek wisata Goa Pindul, banyak para pemuda desa Bejiharjo yang memilih untuk bekerja di wilayah lain baik di sekitar Provinsi DIY maupun ke Jakarta. Dalam hal ini, pada pemuda yang produktif cenderung memilih merantau atau bekerja di perusahanperusahaan besar atau bekerja di sektor 
informal di luar desanya. Namun, sejak obyek wisata ini dikembangkan, para pemuda mayoritas memilih bekerja sebagai pemandu wisata terutama mereka yang memiliki tingkat pendidikan sekolah menengah atas. Atau dengan kata lain, beragamnya lapangan kerja di obyek wisata dapat menyerap tenaga kerja sehingga pengangguran dapat dikurangi.

Mendasarkan pada uraian di atas, dapat dikemukakan keberadaan obyek wisata dalam aspek ekonomi telah mampu merubah ketersediaan lapangan pekerjaan suatu masyarakat, salah satunya perubahan pekerjaan di sektor pertanian beralih ke sektor jasa pariwisata. Terdapat konsekuensi dari perubahan tersebut yaitu terjadi peningkatan pendapatan di sektor pariwisata dan sebaliknya terjadi penurunan produktivitas di sektor agraris yang diindikasian dengan sulitnya mencari tenaga kerja di sektor agraris. Secara nyata, objek wisata gua Pindul di desa Bejiharjo telah merubah kondisi ekonomi masyarakat, yang semula masyarakat mengandalkan kehidupannya dengan bertani, berubah menjadi beraneka ragam seperti menjadi pemandu, pedagang makanan maupun sovernir, perubahanperubahan itu tentunya memiliki dampak baik secara ekonomi maupun secara sosial budaya.

\section{Perubahan sosial-budaya masyarakat obyek wisata}

Interaksi yang intens antar para pelaku yang terjadi di wilayah desa Bejiharjo dapat menyebabkan perubahan nilai, tradisi, dan kebiasaan yang dikembangkan oleh warga masyarakat. Perubahan pada dimensi nilai ini dapat mengarah pada terjadi transformasi transmisi nilai baik positif maupun negatif. Terkait ini, hasil penelitian menunjukkan bahwa pada masyarakat desa Bejiharjo, nilai-nilai baik, yang diwujudkan dalam kebiasaan atau budaya warga masyarakat, masih cenderung dipertahankan di masyarakat. Kehadiran dan perkembangan obyek wisata tidak mengakibatkan tradisi yang ada di Desa Bejiharjo menghilang.
Bahkan, pada pelaku wisata Wira Wisata, kesenian gejok lesung dikemas sedemikian rupa dan diintegrasikan dalam kegiatan pariwisata Ha ini dikemukakan oleh Mbah G, seorang pengelola Pokdarwis Pancawisata, bahwa,

"Adanya objek wisata, harus dilakukan secara professional serta dapat mengatur waktu seefisien mungkin agar ketika jadi pemandu tetap jalan, kegiatan sosial juga jalan seperti kenduri, menolong ketika ada musibah, bahkan lebih efisiean karena sekarang memiliki fasilitas (HP, walki talky, dsb)" (Wawancara 04/09/2015).

Pendapat yang senada dengan kedua informan di atas juga dinyatakan oleh salah seorang perangkat desa Bejiharjo. Ia menyatakan bahwa walaupun banyak warga masyarakat yang bekerja di objek wisata, baik sebagai pemandu, maupun yang pekerjaan lainnya, kegiatan sosial seperti rosulan, bersih desa, kenduri dan sebagainya yang mana sudah berjalan lama dan berkembang di masyarakat masih tetap dipelihara dan dijalankan. Warga masyarakat masih nguri-uri tradisi-tradisi yang sudah ada sebelumnya bahkan saat ini pelaksanannnya lebih semarak karena pendanaanya lebih banyak.

Perubahan perilaku terjadi pada individu warga masyarakat yang langsung berhubungan dengan para pengunjung. Artinya, interaksi dan komunikasi yang lebih sering dengan pengunjung menyebabkan mereka merasa perlu mengubah kebiasaan yang kurang tepat atau sesuai dengan pekerjaan yang sedang dilakukannnya. Mereka menyadari bahwa tindakan dalam memberikan layanan jasa wisata tidak sama dengan perilaku dalam memproduksi barang di perusahaan. Mereka menyadari bahwa bekerja sebagai pemandu dituntut untuk lebih sabar terhadap perilaku pengunjung, selalu menggunakan komunikasi yang sopan, dan sedapat mungkin dapat membina hubungan yang akrab dengan para pengunjung obyek wisata, seperti 
dikemukakan oleh Slmt, seorang pemandu wisata Wira Wisata. Hal senada disampaikan oleh salah seorang istri tokoh masyarakat, LR, bahwa keterlibatannya sebagai penyediaan kuliner bagi para pengunjung dalam kegiatan Pokdarwis Wira Wisata yang ada di wilayahnya, menjadinya dirinya berpandangan ke depan mengenai bagaimana mengembangkan masyarakat di wilayahnya.

Berdasarkan pendapat-pendapat di atas, dapat disimpulkan bahwa walaupun adanya objek wisata berkembang di masyarakat, namun tidak melunturkan adanya kegiatan sosial yang telah tertanam selama ini seperti ada acara rosulan, merdi dusun, dan kegiatan kegiatan sosial yang lainnya, bahkan lebih meningkat karena adanya fasilitas yang dimiliki, dan mampu membangun perasaan senang dan perpandangan ke masa depan.

\section{Peningkatan partisipasi pelaku wisata dan masyarakat terhadap pendidikan}

Dilihat dari peningkatan partisipasi

pelaku wisata dan masyarakat terhadap pendidikan dengan adanya objek wisata Goa Pindul terjadi peningkatan kebutuhan pendidikan terutama yang berupa pelatihan bahasa asing terutama bahasa Inggris. Hal ini disebabkan masuknya turis asing yang berakibat pada mau atau tidak para pelaku wisata harus menguasai bahasa Inggris sebagai akibat promosi wisata yang intens kepada masyarakat luas. Kebutuhan pendidikan lain adalah peningkatan kompetensi kepemanduan dan kemampuan mengelola layanan wisata yang menunjang keberadaan obyek wisata Goa Pindul. Terkait ini, banyak organisasi pemerintah maupun masyarakat yang menyelenggarakan kegiatan pendidikan bagi para pelaku wisata Goa Pindul. Misalnya, Universitas Sanata Dharma memberikan layanan pendidikan kepada para pemandu yang ada di operator Wira Wisata dalam hal peningkatan kemampuan berbahasa Inggeris. Universitas Negeri Yogyakarta melalui program pengabdian kepada masyarakat memberikan berbagai pendidikan dan latihan dalam rangka meningkatkan layanan pemanduan, kuliner, dan produksi souvernir, dan pengembangan remaja. Begitu pula, kegiatan tanggung jawab sosial salah satu bank swasta diwujudkan dalam kegiatan pengembangan kemampuan layanan wisata dan pemasarannya bagi para pelaku di semua operator yang diteliti. Perilaku yang tidak jauh berbeda pun dilakukan oleh instansi terkait khsusus Dinas Pariwisata Kabupaten Gunungkidul, bahkan pada penataan peraturan pengelolaan obyek wisata ini.

Aktivitas pendidikan pun dilakukan sendiri orang masing-masing operator dalam rangka meningkatkan kualitas sumber daya manusianya. Mereka menyadari bahwa kepuasan pengunjung sangat tergantung oleh perilaku melayani para pemandu. Perilaku yang baik diharapkan dapat menimbulkan kepuasan pengunjung yang akhirnya menjadikan mereka menjadi lebih memiliki pemikiran yang baik dan tidak merasa dikecewakan. Oleh karenanya, pembelajaran untuk meningkatkan kemampuan dilakukan sebagaimana dikemukakan oleh perangkat desa dan para pengelola Pokdarwis Dewabejo yang menyatakan bahwa dalam rangka meningkatkan kemampuan kelompok sadar wisata telah melakukan berbagai pendidikan dan pelatihant antara lain: pelatihan bahasa Inggris bagi pemandu, manajemen keuangan, dan juga pelatihan untuk meningkatkan partisipasi pelaku pariwisata.

Hal lain adalah pendirian sekolah Pindul yang sengaja didirikan untuk mendidik anak-anak usia dini di sekitar wilayah objek wisata dan bertempat tidak jauh dari objek wisata Goa Pindul tepatnya di sekretariat Wirawisata. Di antara pengelola obyek wisata di kawasan ini, hanya operator ini yang mengembangkan ide mendirikan sekolah. Sekolah pindul bertujuan untuk memberikan layanan pendidikan untuk anak-anak di wilayah sekitar khususnya Dusun Bejiharjo. Salah seorang pengelola Wirawisata, pak, $\mathrm{H}$, menyatakan bahwa: 
"Di sini selain para pemandu dan pengelola wisata ini ditingkatkan kemampuannya dalam bidang bahasa, ketrampilan pemanduan serta manajemen, tetapi juga mendirikan sekolah Pindul yang di dalamnya terdapat pendidikan anak usia dini, pendidikan out bond sehingga pengunjung setelah menyusur gua kembali ke sekretariat bisa menikmati luculucunya anak-anak PAUD yang sedang bermain, juga bisa menikmati beragam pelatihan out bond yang memang dirancang untuk berbagai kelompok masyarakat" (Wawancara 04/09/2015)

Untuk meningkatkan kualitas sumber daya manusia yang ada di lingkungan Bejiharjo, para pengelola obyek wisata memandang bahwa pendapatan yang diperoleh dari kegiatan layanan wisata tidak hanya diperuntukkan seluruhnya untuk kepentingan para pelaku wisata misalnya untuk penggajian personalia, pemeliharaan peralatan wisata, dan pengembangan kegiatan penunjang wisata, namun sebagian hasil keuntungan diberikan untuk layanan atau bantuan sosial, kas desa, dan pengembangan pendidikan anak usia dini. Para pengelola memandang bahwa warga masyarakat yang ada di lingkungannya terutama anakanak agar menjadi lebih baik di kemudian hari. Yd, seorang pengelola, menyatakan bahwa: "kami pun memberikan bantuan kepada lembaga pendidikan anak usia dini yang ada di dusun agar mereka maju".

Berdasarkan informasi-informasi di atas dapat disimpulkan bahwa adanya objek wisata Goa Pindul menimbulkan berbagai kebutuhan pendidikan bagi para pelaku wisata maupun masyarakat. Adanya kebutuhan pendidikan telah menimbulkan partisipasi masyarakat maupun pelaku wisata dalam memenuhi kebutuhan pendidikan, khususnya dalam peningkatan kemampuan dan keterampilan dirinya, dan munculnya kepedulian dari pengelola objek wisata untuk mendirikan pendidikan nonformal dalam bentuk pendidikan anak usia dini, yang dapat menarik CSR dari BCA untuk membiayai penyelenggaraan pendidikan tersebut.

\section{Pola jejaring yang dibangun pelaku wisata}

Para pelaku wisata harus memiliki kapasitas jejaring yang dimaknai sebagai kemampuan berkomunikasi dan bekerja sama dengan sesama pelaku bisnis atau usaha Kemampuan ini mengarah pada pencapaian (a) sumber daya seperti tenaga kerja, manajer, dan sistem informasi, (b) proses bisnis seperti proses penjualan, dan unit usaha seperti kegiatan dalam rantai pemasokan. Kemampuan membina jejaring bagi organisasi wisata merupakan suatu modal yang harus dimiliki oleh pengelola obyek wisata dalam menghadapi persaingan usaha dan kemajuan perkembangan masyarakat. Hal ini disebabkan suatu kegiatan usaha tidak lepas dari pihak lain yang mencakup mitra, pelanggan, investor, pesaing, pemerintah, pengaruh industri, media massa dan press, vendor, dan assosiasi.

Terkait hal di atas, kelompok sadar wisata berupaya membangun jejaring dengan pihak lain agar dapat menarik wisatawan baik domestik maupun manca. Upaya membangun jejaring telah banyak dilakukan oleh pengelola baik dengan para pelaku wisata yang ada di Bejiharjo maupun dengan lembaga lain. Jejaring wisata yang dikembangkan oleh pada pelaku wisata nampaknya tidak banyak perbedaan. Mereka menjalin hubungan baik dengan perbankan untuk mendukung pembiayaan, maupun dengan lembaga lain seperti SAR, untuk pelatihan pemanduan, dan tentunya dengan pemerintah desa maupun dinas pariwisata kabupaten Gunungkidul. Hal ini sebagaimana dikemukakan oleh pengelola pokdarwis Dewa Bejo, AS, yang menyatakan:

"untuk mengembangkan wisata gua pindul kita telah menjalin kemitraan dengan dinas kebudayaan DIY, dinas pariwisata 
Gunungkidul, menjadi anggota PHRI, sehingga jika ada kegiatan selalu diketahui, juga melalui media sosial seperti facebook" (Wawancara,.04/09/2015).

Sementara itu salah seorang pengelola dari Wirawisata menyatakan untuk menjalin kemitraan dilakukan selain dengan pihak pemerintah kabupaten, kemitraan dilakukan pula dengan menggandeng karang taruna desa, pemerintah desa, biro travel dan perkumpulan kuliner, serta menyalin kemitraan dengan perbankan (BCA) untuk pembiayaan. Apa yang dilakukan oleh kelompok sadar wisata Dewabejo dan Wira Wisata, tidak jauh berbeda dilakukan oleh kelompok sadar wisata Pancawisata.

Di bawah ini gambar mengenai jejaring pelaku wisata yang terjadi atau dilakukan oleh kelompok sadar wisata yang ada di Bejiharjo. Nampak, bahwa di antara pelaku wisata terjadi hubungan dalam pengelolaan obyek wisata yang dikembangkan terutama dalam hal koordinasi pengaturan para pengunjung yang akan memasuki obyek wisata Goa Pindul. Artinya, persaingan antar pengelola wisata disadari ada dan terjadi dalam pengelolaan obyek wisata, namun karena ada kesepahaman bahwa dalam pengelolaan obyek wisata diharapkan tidak terjadi kekacauan dan konflik yang dapat merugikan para pengunjung yang akhirnya berdampak pada penurunan pendapatan para pelaku wisata Goa Pindul dan masyarakat sekitar.

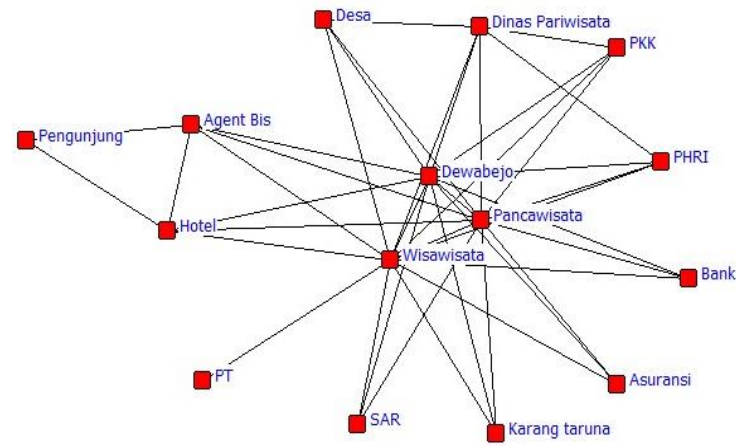

Gambar 1. Jejaring Pelaku Wisata di Bejiharjo

Berdasarkan hasil wawancara dengan pelaku wisata, yang terdiri dari Dewabejo, Pancawisata dan Wirawisata, pelaku wisata menjalin hubungan dengan pihak lain dalam beberapa aspek yang pada dasarnya dimaksudkan untuk meningkatkan jumlah pengunjung, keteraturan dalam obyek wisata, peningkatan permodalan, regulasi dan akses terhadap obyek wisata. Hasil kerja sama dimaksud dapat disampaikan dalam tabel di bawah. Tabel 3 menunjukkan bahwa para pelaku wisata hampir tidak jauh berbeda dalam mengembangkan jejaring dalam pengelolaan usahanya baik dalam hal peningkatan kunjungan tamu, permodalan, transportasi, akomodasi, keamanan, dan sebagainya. Atau dengan kata lain, para pelaku wisata mengembangkan jejaring dengan para pelaku yang masih berada atau berkecimpung dalam dunia bisnis perpariwisataan, dan pelaku-pelaku di sektor lain masih belum banyak terlibat. 
Tabel 1. Aspek Kerjasama

\begin{tabular}{|l|l|l|l|}
\hline \multirow{2}{*}{ Aspek Kerja sama } & \multicolumn{3}{|c|}{ Pelaku Wisata } \\
\cline { 2 - 4 } Tamu & \multicolumn{1}{|c|}{ Dewa Bejo } & \multicolumn{1}{|c|}{ Panca Wisata } & \multicolumn{1}{|c|}{ Wira Wisata } \\
\hline Modal & $\begin{array}{l}\text { PNPM } \\
\text { BPD, BRI }\end{array}$ & $\begin{array}{l}\text { Agent } \\
\text { Kaya Bangtaruna }\end{array}$ \\
\hline Akomodasi & $\begin{array}{l}\text { Hotel di Kabupaten } \\
\text { Gunungkidul } \\
\text { Homestay }\end{array}$ & $\begin{array}{l}\text { Hotel di Kabupaten } \\
\text { Gunungkidul }\end{array}$ & BCA \\
\hline Transportasi & Agent wisata & Agent wisata & Agent wisata \\
\hline Keamanan & $\begin{array}{l}\text { SAR Kabupaten } \\
\text { Polsek dan Polres }\end{array}$ & Asuransi & Asuransi \\
\hline Regulasi & Dinas pariwisata & Dinas pariwisata & Dinas pariwisata \\
\hline $\begin{array}{l}\text { Peningkatan } \\
\text { Kemampuan }\end{array}$ & Lembaga Kursus & Lembaga Kursus & $\begin{array}{l}\text { Omah Pasinaon } \\
\text { UNY } \\
\text { USD }\end{array}$ \\
\hline
\end{tabular}

Berdasarkan hasil wawancara dengan para pengelola objek wisata yang ada di desa Bejiharjo, dapat disimpulkan bahwa keberhasilan mereka dalam pengelolaan objek wisata hingga menjadi ramai seperti yang terjadi saat ini dikarenakan adanya jalinan kerjasama atau membangun jejaring baik antar pelaku wisata maupun dengan pihak stakeholder yang lain yang saling menguntungkan satu sama lain.

\section{Kendala yang dihadapi pelaku wisata}

Daya tarik suatu desa wisata sangat dipengaruhi beberapa faktor yang mempengaruhi tingkat kedatangan pengunjung baik menyangkut ketersediaan infrastruktur yang baik, pelayanan wisata, dan fasilitas penunjang lainnya. Hasil penelitian menunjukkan bahwa dalam pengelolaan obyek wisata terdapat beberapa kendala yaitu: pertama, pada awal perkembangan objek wisata Goa Pindul, akses pengunjung baik lokal maupun manca negara masih kurang memuaskan. Kedua, kendala lain yang dihadapi dalam pengembangan objek wisata berkaitan dengan birokrasi pemerintahan setempat yang dipandang menyulitkan warga masyarakat untuk mengembangkan obyek wisata Goa Pindul.
Birokasi yang menghambat salah satunya adalah perencanaan pengembangan desa wisata Bejiharjo akan dilaksanakan apabila dukungan sumber daya sudah tersedia. Ketiga, kekurangtersediaan modal yang mencukupi untuk mengembangkan kegiatan layanan wisata, dan pengembangnan ekonomi pendukungnya. Keempat, adanya pungutan liar yang dilakukan oleh oknum yang menyebabkan pengunjung jadi tidak nyaman. Terakhir adalah pengaturan pengunjung tidak tepat akan berpengaruh pada kenyamanan para pengunjung.

Berdasarkan hasil wawancara di atas disimpulkan bahwa kendala yang dialami oleh pelaku wisata maupun masyarakat sekitar Gua Pindul dalam pengembangan desa wisata: masih belum baiknya jalan masuk ke lokasi wisata, jarak antara lokasi wisata dengan jalan utama, sulitnya birokrasi pemerintah setempat, adat istiadat yang masih kental, lemahnya sumber daya manusia, permodalan, adanya pungutan liar, dan mengatur jalan masuk ke goa Pindul pada saat hari libur.

\section{Pembahasan}

Sebagai pusat pertumbuhan ekonomi baru, obyek wisata Goa Pindul merupakan suatu kawasan yang potensial untuk terus 
dikembangkan di masa depan. Potensi ekonomi yang mungkin dapat didayagunakan warga masyarakat berawal dari pengoptimalan potensi alam yang menyediakan keindahan. Artinya, pengembangan obyek wisata Goa Pindul didasarkan pada pemahaman dan pengembangan potensi kearifan lokal untuk kemakmuran warga masyarakat. Hal ini menunjukkan pengembangan ekonomi suatu masyarakat dapat dilakukan dengan mengedepankan kebermanfaat dari keuntungan komperatif baik sumber daya alam, maupun sumber daya manusianya, dan didasarkan pada kesiapan dan partisipasi warga masyarakat yang menjadi sasaran akhir dari kegiatan pengembangan ekonomi. Terkait ini, hasil penelitian menunjukkan bahwa pengembangan kawasan Goa Pindul dilakukan dengan memperhatikan peluang yang baik dari keindahan alam berupa goa sebagai sesuatu yang tidak dimiliki oleh warga masyarakat lain.

Adanya objek wisata berakibat terjadi perubahan struktur perekonomi masyarakat. Struktur ekonomi masyarakat mencakup perekonomian di sektor primer, sektor sekunder, dan sektor tersier. Pada masyarakat Bejiharjo, terjadi pergeseran yang mencolok dalam aktivitas perekonomian warganya yaitu perpindahan dari aktivitas perekonomian primer yang ditandai dengan proses produksi di pertanian, pertambangan, dan perikanan. Beralih ke sektor jasa atau skunder (Boediono, 1996:48), di mana layanan wisata menjadi salah satu aktivitas perekonomian di masyarakat Bejiharjo. Adanya pergeseran ini berimplikasi pada penurunan produktivitas di sektor primer karena pekerja produksi di sektor primer beralih menjadi pemandu, pengelola, dan pekerjaan lainnya. Di lain hal, warga masyarakat yang beralih pekerjaan dituntut untuk menyiapkan diri dan membekali diri dengan kompetensi yang sesuai di sektor jasa. Hal ini lah yang nampaknya lambat laun kualitas para pelaku wisata dikembangkan baik secara internal maupun oleh pihak eksternal.
Perubahan atau dampak yang bersifat sosial budaya dengan adanya wisata alam Gua Pindul, lebih banyak disebabkan oleh nilai-nilai yang dianut dan diyakini oleh masyarakat, jika suatu masyarakat setempat memegang nilai-nilai sosial, seperti adanya tradisi atau adat istidat yang kuat, maka adanya perbedaaan nilai-nilai sosial yang berasal dari luar tidak akan banyak berpengaruh, hal ini yang terjadi di objek wisata alam desa Bejiharjo, walaupun secara umum adanya objek wisata akan berdampak pada perubahan kultur dari masyarakat sekitar objek wisata. Keunggulan atas alam yang indah membutuhkan sumber daya manusia yang mampu mengelolanya, salah satunya dengan memiliki kemampuan membangun jejaring. Kemampuan membangun jejaring berarti segala sikap, pengetahuan, dan keterampilan yang baik guna menjalin berhubungan dengan pihak lain untuk mendapatkan sumberdaya. Artinya para pengelola obyek wisata perlu bekerja sama, berkoordinasi, dan bermitra dalam rangka memasarkan layanan pariwisata kepada pihak lain yang potensial misalnya organisasi swasta, perbankan, perguruan tinggi, pemerintah, dan sebagainya. Temuan penelitian menunjukkan bahwa para pelaku wisata sudah mampu membangun jejaring dengan cara yang relatif tidak jauh berbeda dalam rangka mengembangkan aktivitas layanan wisata, walau jejaring yang dibangun masih dilakukan dengan para pihak yang memiliki kegiatan sejenis. Adanya perbedaan dalam kompetensi membangun jejaring berakibat pada banyak atau sedikitnya pengunjung yang menikmati keindahan alam dimaksud.

Para pelaku wisata harus menguasai dan menerapkan kemampuan membangun jejaring baik dengan pihak eksternal maupun dengan sesama pelaku. Cara membangun jejaring yang mungkin dapat dilakukan oleh mereka adalah membina jejaring dengan berbagai pihak dengan strategi, yaitu: penguatan hubungan dengan pengunjung atau para agen wisata, dengan menggunakan teknik pemasaran 
dan evaluasi setelah pengunjung merasakan layanan wisata, menfokuskan pada manajemen rantai penyediaan (layanan wisata yang meliputi sumber daya, perencanaan, pembuatan, dan pengantaran; dan memfokuskan pada proses transaksi dan keterkaitan berbagai proses bisnis (Alt, Puschmann, Reichmayr, 2001:90). Hal lain adalah para pelaku wisata perlu memahami pentingnya berkoneksi dengan orang lain, memiliki sikap positif dan otentik, mengutamakan mutu berjejaring, memegang etika jejaring, berkomunikasi dengan efektif dan dialogis, dan selalu bersikap positif dalam berjejaring untuk mendapatkan pekerjaan (Kramer, 2012:76).

\section{PENUTUP}

\section{Kesimpulan}

Berdasarkan hasil penelitian dan pembahasan dapat ditarik kesimpulan yaitu: pertama, keberadaan objek wisata Goa Pindul yang pertama kali dikelola oleh pokdarwis Dewa Bejo pada tahun 2010, telah menyebabkan beberapa perubahan baik secara ekonomi maupun secara sosial budaya, perubahan dalam perekonomian masyarakat ditandai dengan: a) terjadi perubahan dalam jenis pekerjaan yang dimiliki oleh pelaku wisata maupun masyarakat sekitar objek wisata dan berakibat pada peningkatan pengetahuan.; b) secara sosial budaya perubahan yang terjadi lebih cenderung pada perubahan perilaku individu warga masyarakat dan nilai, tradisi dan adat kebiasaan yang ada di masyarakat Bejiharjo masih relatif tidak berubah atau masih dipertahankan serta terjadi peningkatan kebutuhan pendidikan. Kedua, pola jejaring yang terbangun diantara para pelaku wisata Goa Pindul yang tidak mengindikasikan ada perbedaan keragaman hubungan dengan pihak lain dalam mencari sumber daya, fasilitas, pendampingan maupun pengakuan. Dalam hal ini, jejaring yang dibangun oleh para pelaku wisata Goa Pindul lebih banyak dilakukan dengan pihak yang memiliki kesamaan kepentingan atau perhatian dalam pengembangan kepariwisataan di Kabupaten Gunungkidul antara lain agen wisata, perhotelan, pelaku wisata sejenis, perbankan, pemerintah setempat, dan perguruan tinggi.

\section{DAFTAR PUSTAKA}

Alt R., Puschmann T., \& Reichmayr C. (2001) Strategies for Business Networking. In: Business Networking. Berlin, Heidelberg: Springer.

Boediono. (1996). Pendidikan dan Perubahan Sosial. Yogyakarta: Rineka Cipta.

Dinas Pariwisata DIY. (2013). Statistik Pariwisata DIY. Diakses dari http://visitingjogja.web.id/bank_da ta/display/Statistik+Pariwisata+20 13.

Kramer, E. (2012). 101 Successful Networking Strategy. Boston: Course Technology, Cengage Learning

Miles, B. M. \& Huberman, A. M. (2007). Analisis Data Kualitatif. Terjemahan. Jakarta: UI-Press

Yin, Robert. (2003). Case study research. New York: Sage publication, Inc. www.krjogja.com. (2014). Kisruh Goa Pindul Rusak Citra Pariwisata DIY?. Diakses pada 17 Maret 2015. 